\title{
Exercising in Urban Environment during COVID-19 Pandemic
}

\author{
Said Junaidi \\ \{said.ikor@mail.unnes.ac.id\} \\ Universitas Negeri Semarang, Semarang, Indonesia
}

\begin{abstract}
During Covid-19 pandemic, people were expected to implement health protocols, one of them was by exercising to increase body immunity. This study aims to analyze sports activities during Covid-19 pandemic. The researcher used a quantitative descriptive. The subjects were urban people aged 12-55 years. The results of the study are 1) During covid-19 pandemic, sports activities are quite good (83\%), 2) Women are more active in exercising than men (53\%). 3) The age of people who actively exercise is around 12-35 years $(66.7 \%) .4)$ The frequency of exercising done once a week is $37.7 \%$ and the sports activities carried out more than 3 times a week is $38 \%$. 5) Duration of doing sports is around 15-30 minutes (50.6\%). 6) The types of exercise that popular are walking $(30.3 \%)$ and jogging $(55 \%)$. It can be concluded that sports activities in urban communities during covid-19 pandemic are included in the good category.
\end{abstract}

Keywords: exercise, urban environment, covid-19

\section{Introduction}

During the corona virus disease pandemic 2019 (covid-19), almost all people experienced high concerns. Concerns occur not only in urban communities but also in rural communities. Until now, no vaccine has been found that can stop the rate of transmission of the corona virus. Covid-19 is a new disease that has become a pandemic in various parts of the world. This disease must be suspicious because the rate of its transmission is relatively fast. It has a mortality rate that cannot be underestimated and there is no definitive therapy or medical treatment that can help to manage the disease. In addition, there are still knowledge gaps dealing with this corona virus, so then further studies are needed [1]. Efforts that can be done are as much as possible to avoid the risk of transmission of the virus through the application of health protocols. The goal is actually to minimize the risk of infection through an increase in a healthy lifestyle, one of which is to exercise regularly and safely.

Various non-infectious diseases that have emerged in the midst of society, one of which is caused by the habit of exercising does not become part of the daily lifestyle. A relatively passive lifestyle will cause physical weakness as a result of 
hypokinetic. Hypokinetic causes rapid weakness in physiological functions due to degenerative processes. This causes the work productivity to be decreased or disrupted and even very likely to be stopped. The habit of exercising is expected to become the needs of the community as well as the need for drinking and eating. Regular and programmed exercise will have a positive impact on health / fitness as well as people's growth and development. In addition, it can also have a positive impact on body health and fitness which can then have an effect on increasing work productivity as well. Moreover, doing sports activities can also reduce / slow the occurrence of degenerative processes for the elderly.

Government agencies and NGOs around the world are increasingly aware of the role of sports in filling leisure time with doing some physical activities that can reduce barriers and social strife as well as reduce violence in society [2]. A number of international sports researchers and humanitarian agencies suggest that the positive impact of sport is a need to improve individuals, cultures, and societies [3]. The United Nations through the charter of resolution 58/5 of 2003 states that sport is an effective media as a tool to show the strength of the nation in the international community [4].

Sporting activities is the intentional use of sports, physical activity, and games to achieve the specific development goals of a nation [5]. Sport has been able to be an important part of the process to achieve the goals of fostering physical fitness, growth and development of movement, mental, moral, attitudes, and behavior in accordance with the noble values of the nation. Even John Fitzgerald Kennedy, the 35th President of the United States, once said that fitness is the basis for all other forms of excellence. Development of physical fitness and health contribute to the effectiveness of life and enjoyment of life [6].

The results of a research in Sweden concluded that exercise as a tool for the development of adolescents towards a positive direction. There is evidence of a correlation between sports involvement and self-esteem, sharpening physical competence, social competence [7]. Sport is able to unite differences in race, religion, ethnicity, gender as well as a reliable drug to cure social ills [8]. Sports activities can shape the character, knowledge and skills of the community to be more positive, including teenagers and young people.

The results showed that sports participation in a South African city was able to develop youth competencies including enhancing self-concept, discipline, and skills. Furthermore, in India, Kay found that sports-based programs designed to promote leadership in adolescent women can help increase knowledge. Thomson, Darcy and Pearce conducted several case studies of sports programs designed to reduce social injustice that existed between indigenous peoples and Australians. The Hokowhitu Program is an example of a sports-based youth development program targeted at Maori youth. The program has succeeded in generating a positive attitude towards schools, improving skills, and a more optimistic outlook [9].

The importance of examining the relationship between sports participation and morality to determine whether the level of sports participation is related to morals, aggressive tendencies, and judgments about the legitimacy of sporting actions [10]. The results show that there is a positive effect when teenage girls engage in sports or enjoyable physical activities, when they engage with friends, and when they are supported by family and teachers through role modeling and positive feedback [11]. The 
problems of low trends in community for exercising are, first; There is still a lack of research on the relationship between goal orientation and motives for participating in sports and physical activitoes [12].

Second, lack of attention about physical activities patterns and health implications related to immovable behavior so it is important to better understand the dynamics of physical motivation of young people. Third, physical education (including sports) has become an important aspect. The tendency of urban communities to have a decreased movement culture will cause a setback in fitness and physical capacity.

The results of Sylejmani's, Blerim. et al. show that children and adolescents from rural environments have better results in cardiorespiratory fitness, upper muscle fitness, lower extremities, coordination, speed, and agility compared to those who live in urban areas [13].

The behavior of urban communities in Indonesia related to exercise habits tends to decrease. Cyberspace-based advancements in digital and automatic-electric technology have made urban communities given so much convenience. However, during the Covid-19 pandemic there were indications that people had increased awareness about the importance of exercise to enhance their immunity. Prevention of the spread of the corona virus through increased self-defense (immune response) can be done by exercising.

Other prevention are to increase endurance through intake of healthy food, frequent hand washing, wearing masker, doing exercise, getting enough rest, and eating well-done food [14]. When getting sick, immediately seek treatment to the referral hospital for evaluation. The implication for policy is that cross-sectoral initiatives between sports, social and health need to be supported because the effects are directly related to each other [15].

\section{Method}

This study belonged to a descriptive quantitative research. It aimed at analyzing the urban community who exercised during covid-19 pandemic within the perspective of gender, age, frequency, intensity categories, duration, and type of exercise. The population used was a large city community with a range of age from 12 years to 55 years old. Incidental cluster sampling technique was used to determine the subject of the study. Questionnaire and structured interviews were used as a method in collecting the data. The questionnaire was spread via Google Form. The validity of the instrument used is internal validity with the construct validity approach [16]. The research data were analyzed in a narrative and descriptive quantitative and displayed by using percentage approach.

\section{Results And Discussion}

During the establishment of the covid-19 pandemic status by the Indonesian government, people in most regions in Indonesia tended to have high anxiety and panic. This is caused by several factors such as the rapid rate of transmission of the 
virus, the coronavirus vaccines is still unavailable, and the death rate caused by covid19 that cannot be underestimated. Transmission that occurs in large cities is relatively greater than in regions with smaller areas. The number of positive people with covid19 in big cities in Indonesia during 2020 is relatively high.

This then requires the community to actively participate independently to take steps to prevent transmission by implementing health protocols. According to the health protocol, the public is expected to be able to do safe sports to improve fitness that can increase body immune so that it can ward off the corona virus effectively.

This research begins by determining an area that is a major city area and then observing sports activities carried out by people in the region. The division of regions is based on the smallest unit of territory consisting of villages and then developed into districts. The number of sub-districts in this study were 177 sub-districts within 16 districts with an overall area of $373.7 \mathrm{KM}^{2}$ (https://semarangkota.bps.go.id). The population of the big cities in this study was $1,668,578$ people spread in 16 districts and 177 sub-districts

The results of this study show that the number of urban communities engaged in physical activities over the period of one week was $83 \%$, while $17 \%$ of the people did not do physical activities. Furthermore, as many as $53.3 \%$ of the people who like to exercise are female while $46.7 \%$ are male.

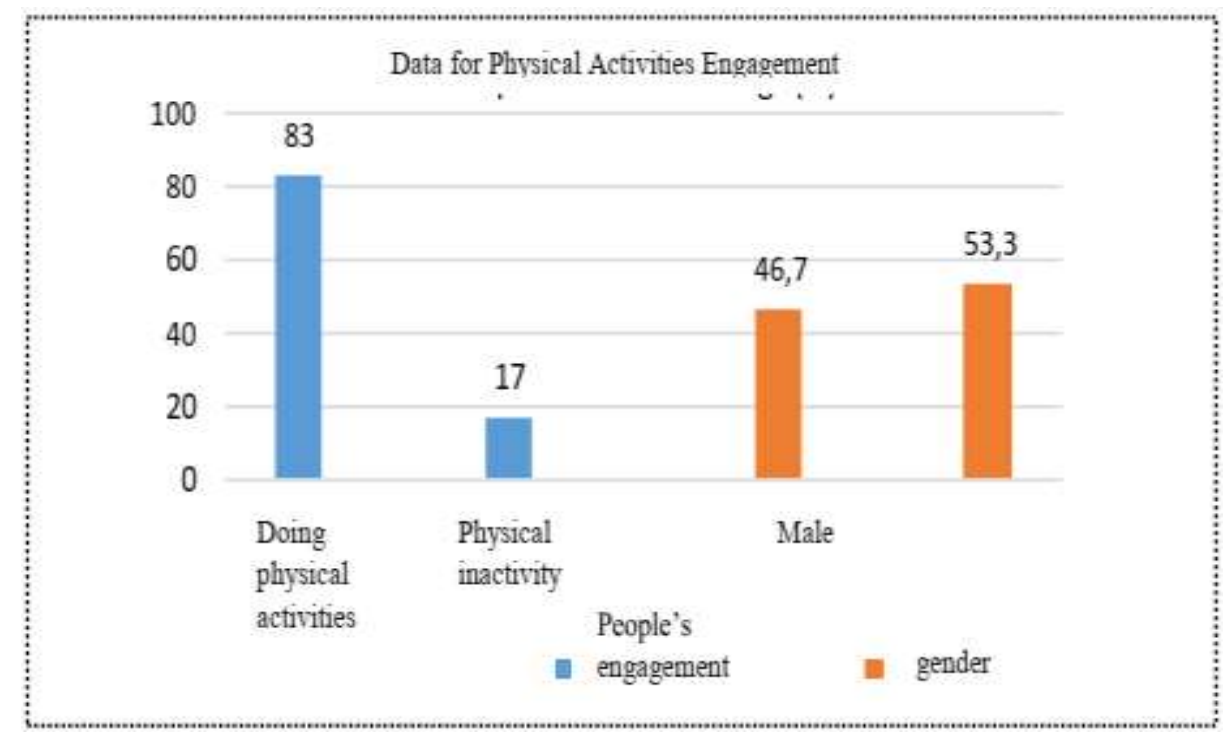

Fig. 1. Data for People's Engagement on Physical Activities based on Gender

Next, a description of the average age of urban people who love doing exercise. Based on the results of the study it was found that as many as $87.5 \%$ people aged 12 35 years, $11.7 \%$ people aged $36-55$ years, and $0.8 \%$ aged over 55 years. 


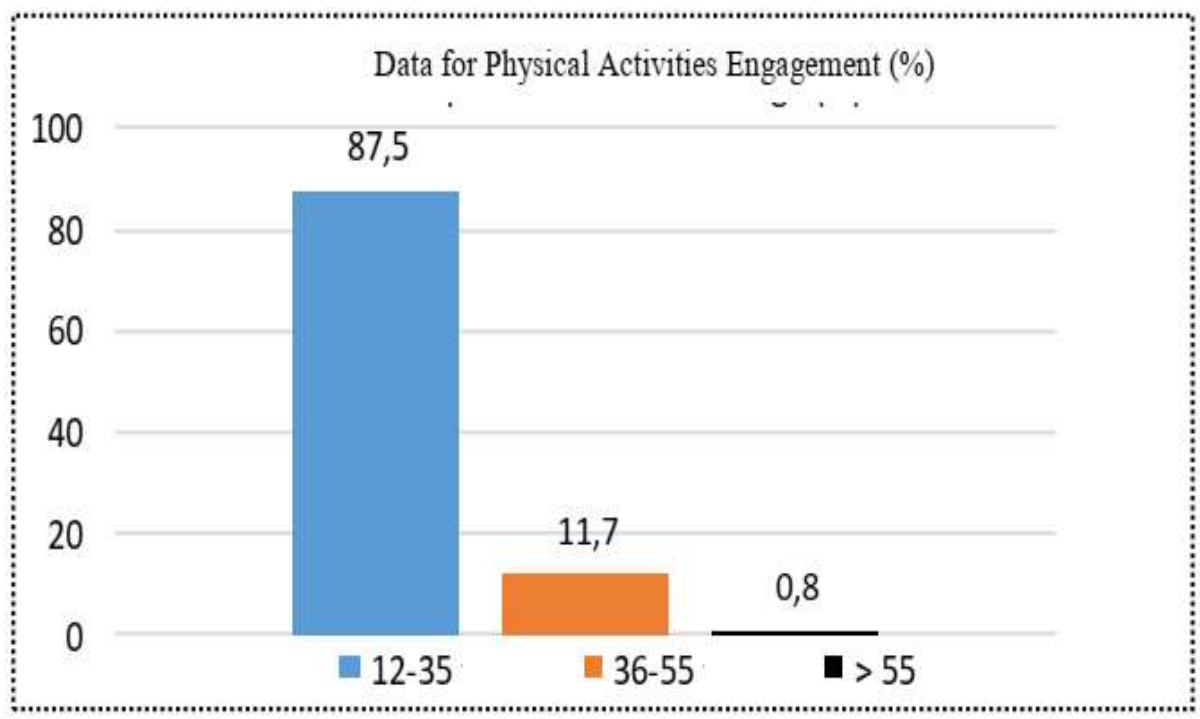

Fig. 2. Data for People's Engagement on Physical Activities based on Age Group

Based on research data, it is known that $17.5 \%$ people who love doing exercise work as civil servants / Soldiers / Police / Private Employees. As many as $15.8 \%$ are self-employed and the rest $66.7 \%$ are students.

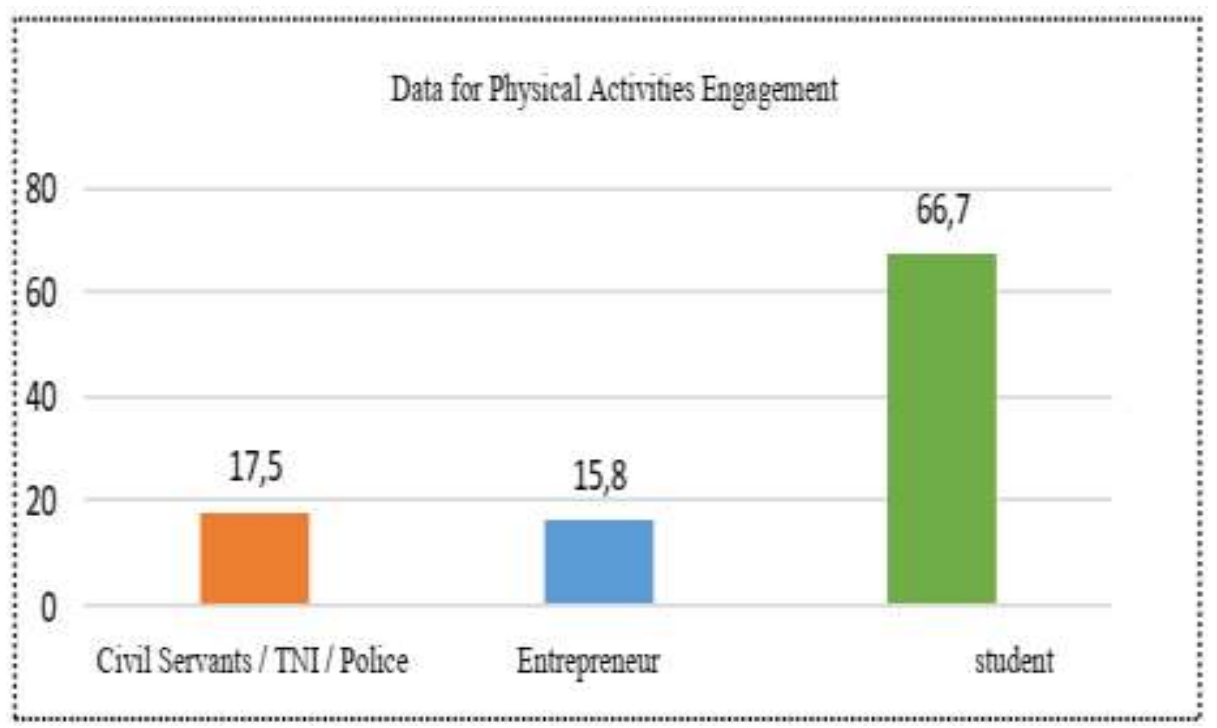

Fig. 3. Data for People's Engagement on Physical Activities based on Occupation 
According to AAHPERD (1999) there are four principles in exercise that can have an impact on changes in fitness, namely FITT (frequency, intensity, time, and type). The frequency of urban communities in doing sports based on research results is that as many as $37.7 \%$ people do exercise once a week. Whereas $24.3 \%$ of people do exercise two times a week, and $38 \%$ of people do exercise more than three times a week.

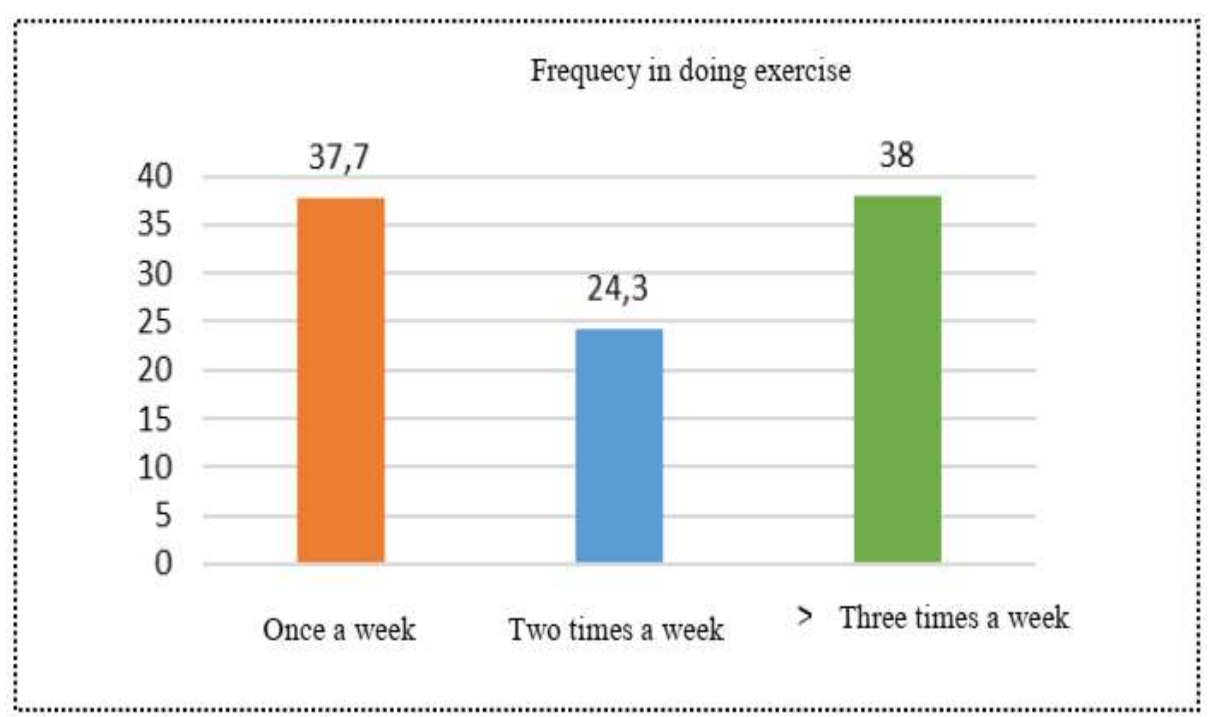

Fig. 4. Data for People's Engagement on Physical Activities based on Frequency

The intensity in exercising is an important factor in determining fitness. But to determine how much the intensity of the exercise is not easy because it must go through a pulse calculation (heart rate). The intensity in this research data is informative and is not based on real measurement because it is obtained only through questionnaire.

Therefore, the category in question is exercising with a perceived burden that is "light, moderate, and vigorous". Based on information from respondents, 52.6\% of people stated that they did some light exercises, while $39 \%$ of people said they did moderate exercises and $8.4 \%$ of people uttered that they did some vigorous exercises. 


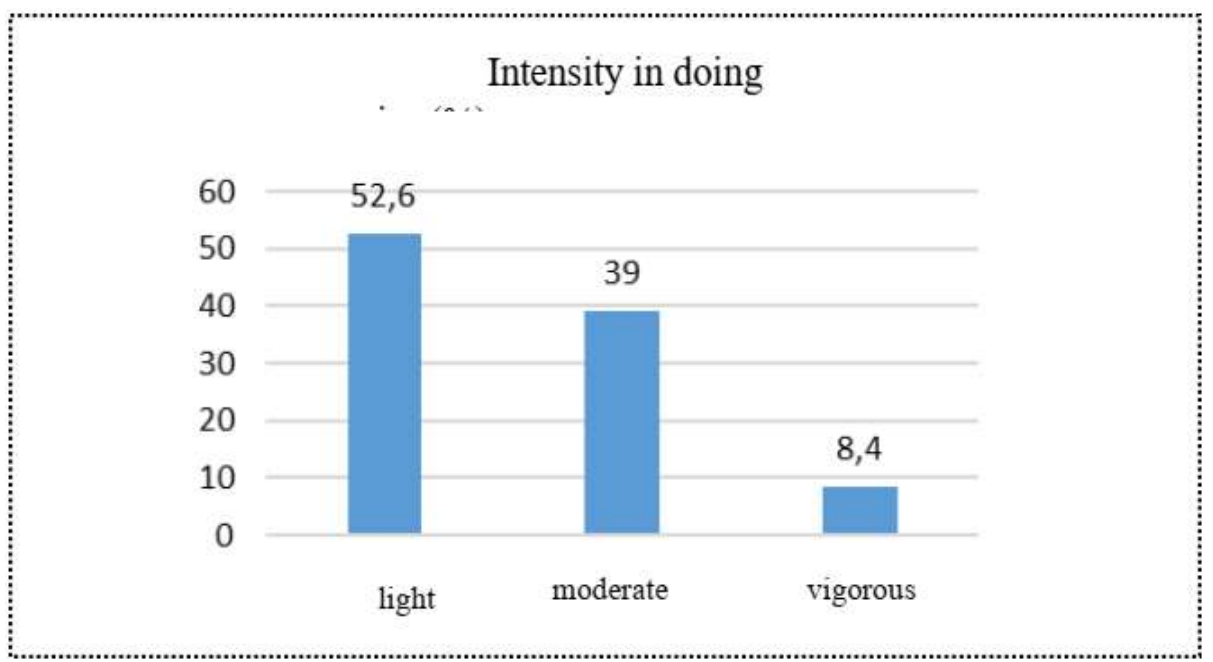

Fig. 5. Data for People's Engagement on Physical Activities based on Intensity

The duration of time in doing exercise is an important factor in providing a physiological effect of exercise. The difference in the amount of time when doing sports will have a different impact on the body. As an illustration, jogging in a relatively long period of time without stopping is included in the low intensity category and gives an effect on general endurance (endurance).

According to information from respondents that $13.6 \%$ of respondents did exercise less than 15 minutes. Most or as many as $50.6 \%$ of respondents did exercise between 15-30 minutes. Then as many as $35.7 \%$ did exercise in a period of more than 30 minutes.

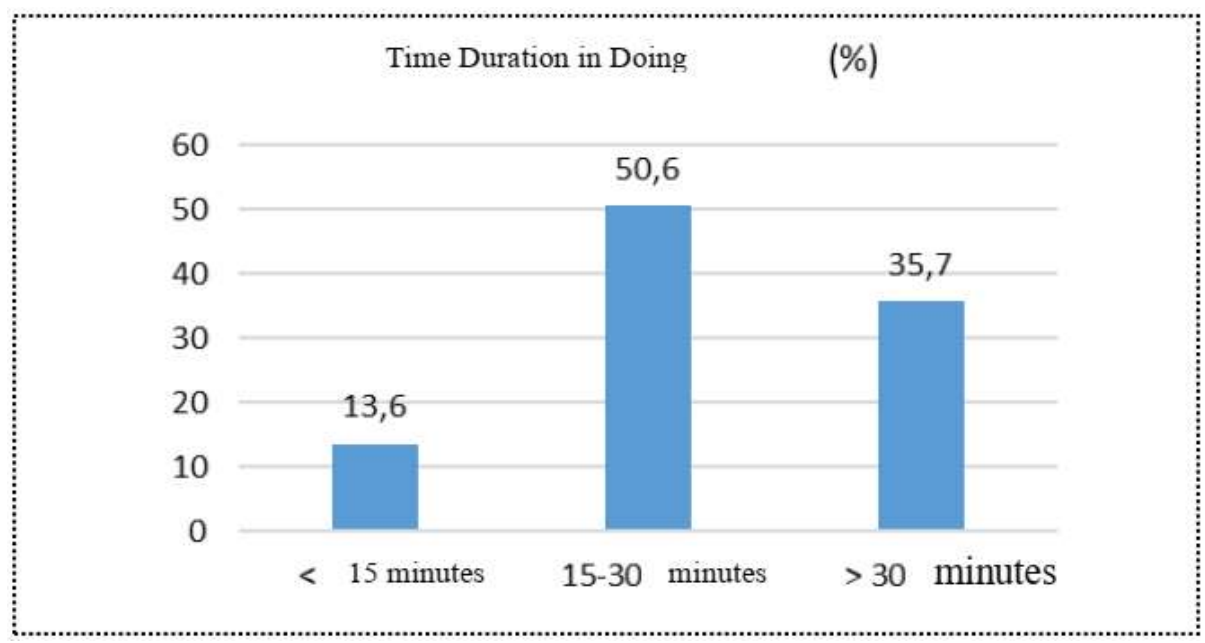

Fig. 6. Data for People's Engagement on Physical Activities based on Time Duration 
Exercises carried out by urban people is one indicator of the model of community involvement / participation on the importance of maintaining physical fitness through sports. Exercise that is practiced regularly and safely can bring about positive changes and give physiological effects. This study divides the types of exercise such as walking, jogging, cycling, swimming, gymnastics, sports games, martial arts, and others. This study gives respondents the opportunity to choose more than one type of exercise.

This means that there are people who exercise more than one type of exercise so that the total percentage is not $100 \%$. The results showed that $30.3 \%$ of respondents go walking, $55 \%$ of respondents go jogging, while $33.8 \%$ of respondents go biking and $12.7 \%$ of respondents go swimming. Meanwhile $12.2 \%$ of respondents do aerobics dance, $38.6 \%$ of respondents play sports game (soccer, futsal, volleyball, basketball, etc.). Then $6.5 \%$ of respondents do martial arts, while $14.7 \%$ of respondents play other sports in accordance with their interest. The results of the study show that during the covid-19 pandemic, many urban people begin to realize and practice various physical activities such as doing some sports. This is a positive indicator that active movement is important in terms of improving the quality of life.

Moreover, during the covid-19 pandemic, it requires everyone to live a healthy lifestyle and actively exercise safely to improve the body's immune response. The habit of doing exercise in urban environment based on this research is characterized by an average of above $50 \%$ of people actively do exercise. Some exercises are also practiced by people from children to adolescents. More than $50 \%$ of urban people do some exercise in accordance with FITT principle (frequency, intensity, time, and type of exercise) so that it is impactful and safe for health.

Healthy lifestyle is one of the efforts to improve health status and quality of life. Among the healthy lifestyle that are expected to be carried out by the people are regular, programmed, and measurable exercise. Sports is recognized as one of the activities that can increase the value of body fitness at all age levels even more so during the covid-19 pandemic. The Lifetime Health Letter reports that men and women aged 65 years or older who walk more than four hours / week are less likely to be treated for heart disease than those who are younger [17].

People's fitness through active living habits in urban areas needs to receive more attention than people in rural / non-urban areas. Changes in the lifestyle of big city communities from active to inactive due to the technology that is completely automatic and electrically makes hypokinetic occur in humans. Diseases arising from lack of movement (hypokinetic) make the quality of health and fitness decrease which impacts on the decreasing quality of the human organ system. Hypokinetic can cause health problems including degenerative / non-infectious diseases [18].

During the Covid-19 pandemic, physical fitness is very important to help improve the immune response which in turn can help ward off the body from being infected by the corona virus. Although there is no good news regarding prevention of covid-19 transmission through vaccines, the application of health protocols is a good alternative for all parties to implement. One suggestion in the health protocol is to exercise safely to improve physical fitness. 


\section{Conclusion}

Based on the results of the study, it can be summed up that people's involvement on physical activities during covid-19 pandemic in urban environment is prone to be well-practiced. Moreover, they relatively implement the fitness training principles to develop their physical fitness as an effort to stay healthy.

\section{Acknowledgements}

We would like to thank Faculty of Sports Science, Universitas Negeri Semarang, Indonesia for the funding.

\section{References}

[1] Adityo Susilo, dkk. 2020. Jurnal Penyakit dalam Indonesia Vol. 7, Nb. 1 March 2020. http://jurnalpenyakitdalam.ui.ac.id/index.php/jpdi/article/view/415/228. accessed 07/07/20.

[2] Schulenkorf, N. Sport for Development Events and Social Capital Building: A Critical Analysis of Experiences from Sri Langka. J. of Sport for Develop. March 2013.1(1). p:25.

[3] Hancock, Meg g, Alexis Lyras, Jae-Pil Ha. Sport for Development Programs for Girls and Women: A Global Assessment. (internet) J. of Sport for Develop. March 2013.1(11). p:41. (cited 8/5/2014).

[4] Hartmann, D et al. Sport Development: An Overview, Critique, and Reconstruction. (internet). J. of Sport \& Sosial Iss. July.29.2011. 35 (3). p:284.

[5] Richards, Justin. Kaufman, Zachary. Wolf, Eli. Gannet, Katie. et al. Advancing the Evidence Base of Sport for Development. J. of Sport Develop. 2013.1 (1) p: 1-3.

[6] Buck, Marliyn M. et.al. Instructional Strategies. For Secondary School Physical Education. New York. Mc Graw Hill Higher Education. 2007 p.18.

[7] Wagnsson, Stefan., Christian A., Göran P. Associations Between Sport Involvement and Youth Psychosocial Development in Sweden: A Longitudinal Study. (internet). J. of Sport for Develop. March 20131 (1). p:37.

[8] Russel Hoye, Nicholson, M. \& Houlihan, B. (). Sport and Policy. Elsevier Ltd 2017 (Vol. 91).

[9] Halsall, T and Tanya Forneris. Challenges and Strategies for Success of a Sport for Development Programme for First Nations Metis and Inuit Youth (internet). J. of Sport Develop. 2016. 4(7). p.40.

[10] Sylejmani, Blerim. Et Al. Physical fitness in children and adolescents in rural and urban areas. (internet) J. of Human Sport and Exerc. 2019.14(4). p:866.

[11] Casey, MM; Eime. RM; Payne, WR; Harvey, JT. Using a Socioecological Approach to Examine Participation in Sport and Physical Activity Among Rural Adolescent Girls. Qualitative Health Research Volume XX Number X. 2009. p:1.

[12] Zahariadis, PN; Hessaloniki, G; Biddle, SJH. Goal Orientations and Participation Motives in Physical Education and Sport: Their relationships in English School children. (internet). The Online J. of Sport Psycho.

[13] Sylejmani, Blerim. Et Al. Physical fitness in children and adolescents in rural and urban areas. (internet) J. of Human Sport and Exerc. 2019.14(4). p:866. (cited 29/01/2019).

[14] Diah Handayani, dkk. (2020: 128) Penyakit Virus Corona 2019. J. Respirologi Indonesia. Volume 40, Nomor 2, April 2020. 
[15] Marlier, Mathieu. et al. . Interrelation of Sport Participation, Physical Activity, Social Capital and Mental Health in Disadvantaged Communities: A SEM-Analysis. (internet). Plos One. October 92015.

[16] Eko Putro W. 2016. Teknik Penyusunan Instrumen Penelitian. Yogyakarta. Pustaka Pelajar.

[17] Widjaja Kusuma. 1999. Bugar Setelah Usia 40. Interaksara. Batam.

[18] Djoko Pekik I. 2000. Panduan Latihan Kebugaran yang Efektif dan Aman. Lukman Offset. Yogyakarta. 